\title{
PEMBERIAN KONSENTRASI ASAM ASETAT PADA MUTU GELATIN KULIT IKAN TUNA
}

\author{
Farah V. Lombu' ${ }^{1}$, Agnes T. Agustin ${ }^{2}$, Engel V. Pandey ${ }^{2}$ \\ 1) Mahasiswa pada Program Studi Teknologi Hasil Perikanan FPIK Unsrat Manado \\ 2) Staf pengajar pada Program Studi Teknologi Hasil Perikanan FPIK Unsrat Manado
}

\begin{abstract}
ABSTRAK
Ikan Tuna (Thunnus albacore) merupakan ikan pelagis besar dan bernilai ekonomis tinggi dan tersebar hampir di seluruh perairan Indonesia. Ikan tuna mengandung protein antara 22,6-26,2 g/100 g daging. Lemak antara 0,2-2,7 g/100 g daging. Menurut Mukhtar (2011) pemanfaatan limbah perikanan berupa kepala ikan, sirip, tulang, kulit dan daging merah telah digunakan dalam beberapa hal, yaitu seperti bakso, sosis, nugget, tepung, isolate protein ikan, juga digunakan dalam pemanfaatan silase dan gelatin. Gelatin merupakan suatu jenis protein yang diekstraksi dari jaringan kolagen hewan, (Tourtellote $\mathrm{P}, 1980)$.Gelatin merupakan salah satu jenis protein yang diperoleh dari kolagen alami yang terdapat dalam kulit dan tulang (Yi et al., 2006). Tujuan penelitian ini untuk mengetahui mutu dari pemberian konsentrasi asam asetat terhadap total bakteri, rendemen dan kadar air gelatin dari kulit ikan tuna. Perlakuan dalam penelitian ini adalah perbedaan konsentrasi asam asetat $(0,3,6$, dan 9\%). Untuk penggunaan bahan baku dalam penelitian ini, berat sampel yang digunakan yaitu sebanyak $4 \mathrm{~kg}$ kulit basah. Penelitian ini menggunakan metode penelitian deskriptif dengan empat kali pengambilan sampel. Hasil dari penelitian ini nilai rendemen yang paling tinggi ada terdapat pada konsentrasi $9 \%(13,93 \%)$ dan yang paling rendah terdapat pada konsentrasi $0 \%(9,6 \%)$. Sedangkan untuk kadar air, kandungan yang paling tinggi terdapat pada konsentrasi $6 \%$ (10,75\%) dang yang paling rendah pada konsentrasi $3 \%$ $(9,1 \%)$, nilai kandungan kadar air pada penelitian ini masih memenuhi standar mutu SNI tentang gelatin (1995) yaitu kadar air maksimal sebesar 16\%. Sedangkan untuk total bakteri, nilai total bakteri pada gelatin ini memenuhi standar minimal yang dipersyaratkan yaitu minimal 1000 (1x103) atau 0,1x104 CFU/gr. Nilai yang paling rendah untuk analisa total bakteri pada penelitian ini adalah terdapat pada konsentrasi $0 \%$ dengan nilai7.8x102 CFU/gr, sedangkan yang paling tinggi terdapat pada konsentrasi 3\% dengan nilai 5.4 x104 CFU/gr. Kesimpulan dari penelitian ini adalah pemberian konsentrasi asam asetat yang berbeda dapat memenuhi standar mutu yang dipersyaratkan untuk gelatin kulit ikan tuna.
\end{abstract}

Kata kunci: Kulit Ikan Tuna, Gelatin, Asam Asetat.

\section{PENDAHULUAN}

Ikan Tuna (Thunnus albacore) merupakan ikan pelagis besar dan bernilai ekonomis tinggi dan tersebar hampir di seluruh perairan Indonesia. Menurut Saanin (1968), Ikan tuna termasuk dalam keluarga scombroidae, tubuhnya berbentuk cerutu, memiliki dua sirip punggung, memiliki jari-jari sirip tambahan (finlet) di belakang sirip punggung dan sirip dubur. Dalam, pemanfaatan limbah perikanan berupa kepala ikan, sirip, tulang, kulit dan daging merah telah digunakan dalam beberapa dapat dibuat tepung, konsent, bubur ikan, juga digunakan dalam pemanfaatan silase dan gelatin (Mukhtar 2011).

Gelatin merupakan salah satu jenis protein yang diperoleh dari kolagen alami yang terdapat dalam kulit dan tulang (Yi et al., 2006). Gelatin banyak digunakan untuk berbagai keperluan industri, baik industri pangan maupun non-pangan karena memiliki sifat yang khas, yaitu dapat berubah secara reversible dari bentuk sol ke gel, mengembang dalam air dingin, dapat membentuk film, mempengaruhi viskositas suatu bahan, dan dapat melindungi sistem koloid. Secara umum fungsi gelatin untuk produk pangan adalah sebagai zat pengental, penggumpal, pengemulsi, penstabil, pembentuk busa, menghindari sineresis, pengikat air, memperbaiki konsistensi, pelapis tipis, pemerkaya gizi, pengawet. (Wiratmaja, 2006). Ikan dapat digunakan sebagai bahan baku pembuatan gelatin. Hal ini dikarenakan pada bagian tertentu dari ikan, misalnya tulang dan kulit, terdapat kolagen yang dengan penambahan perlakuan asam atau alkali serta proses pemanasan menyebabkan kolagen tersebut dapat dikonversi menjadi gelatin.

\section{METODOLOGI PENELITIAN}

\section{Bahan dan Alat}

Bahan yang digunakan dalam penelitian ini adalah kulit ikan tuna sebanyak $4 \mathrm{~kg}$ yang 
diambil di perusahaan produksi PT Blue Ocean Grace di kota Bitung, larutan asam asetat $\left(\mathrm{CH}_{3} \mathrm{COOH}\right)$ dan akuades, dengan konsentrasi asam asetat $(0,3,6$, dan 9\%). Alat yang digunakan adalah oven, water bath, timbangan, pipet, erlenmeyer. Penelitian ini menggunakan metode analisa deskriptif dengan empat kali pengambilan sampel.

\section{SIFAT FISIK GELATIN}

\section{Rendemen}

Nilai rendemen merupakan hasil analisis penting untuk mengetahui tingkat efisiensi dari proses pengolahan. Selain itu rendemen juga dapat dilakukan analisis finansial dimana dapat diperkirakan jumlah bahan baku untuk memproduksi produk dalam volume tertentu

Rendemen diperoleh dari perbandingan berat kering gelatin yang dihasilkan dengan berat kulit yang diekstraksi (AOAC, 1995):

$$
\text { Rendemen }=\frac{\text { Berat Gelatin }}{\text { Berat Kulit }} \times 100 \%
$$

\section{Kadar Air}

Air merupakan kandungan penting dalam suatu bahan pangan. Air dapat berupa komponen intra-sel atau ekstra-sel dari suatu produk. Metode penelitian kadar air, kondisikan oven pada suhu yang akan digunakan hingga mencapai kondisi stabil. Kemudian masukkan cawan kosong ke dalam oven minimal 2 jam. Pindahkan cawan kosong ke dalam desikator sekitar 30 menit sampai mencapai suhu ruang dan timbang bobot kosong (A). Timbang contoh/sampel yang telah dihaluskan dengan blender sebanyak $5 \mathrm{gr}$ ke dalam cawan (B). Masukkan cawan yang telah di isi dengan contoh/sampel ke dalam oven pada suhu $105^{\circ} \mathrm{C}$ selama 16-24 jam. Selanjutnya pindahkan cawan dengan menggunakan alat penjepit ke dalam desikator selama \pm 30 menit kemudian ditimbang (C). Kadar air dihitung berdasarkan persamaan berikut (BSN 2006a dalam Umar 2011):

$$
\text { Kadar air }=\frac{(B-C)}{(B-A)} \times 100 \%
$$

\section{Total Bakteri (TPC)}

TPC/Total Plate Count atau Angka Lempeng Total Perhitungan Lempeng Total digunakan dan dipakai untuk uji mikro di industri, baik itu industri makanan, kosmetik terutama untuk bahan-bahan sampel yang berwujud padat dan cair, baik sampel alami atau pun yang ada di dalam kemasan dari suatu produk. Cara umum tujuan untuk dilakukan TPC ini adalah untuk menentukan total mikroba yang ada pada suatu sampel baik padat ataupun cair dengan metode pengenceran serial dan cawan tuang, dimana pengenceran serial ini merupakan proses pengenceran yang dilakukan dalam beberapa tahap kali pengencerannya, sedangkan setelah dilakukan proses pengenceran, maka akan dituangkan ke dalam cawan Petri untuk dilakukan proses analisa lebih lanjut, yaitu tahap inkubasi dan proses perhitungan jumlah mikroba.

Total bakteri $=$ jumlah koloni $\mathrm{x} 1 /$ faktor pengenceran dengan nilai $11,05 \%$ dan yang paling rendah adalah $0 \%$ dengan nilai $8,6 \%$.

\section{HASIL DAN PEMBAHASAN}

\section{Rendemen}

Nilai rendemen merupakan hasil analisis yang digunakan untuk mengetahui tingkat efisiensi dari proses pengolahan. Rendemen gelatin adalah berat kering yang dihasilkan dari bahan baku kulit yang dalam keadaan bersih diperoleh dari proses ekstraksi

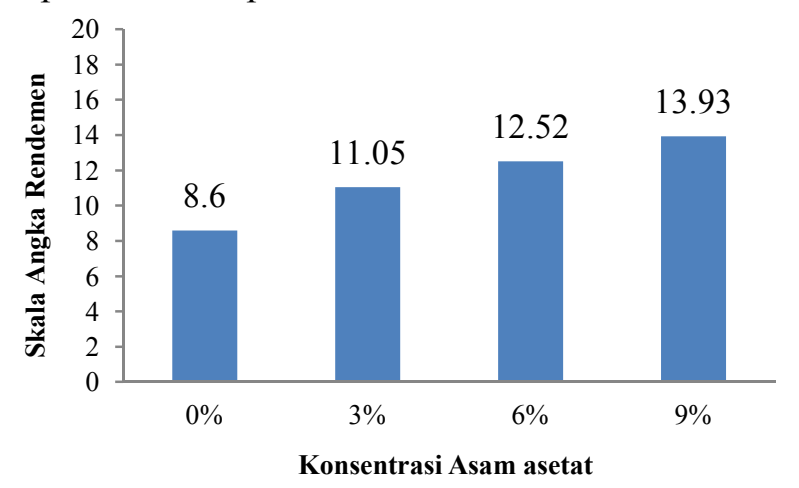

\section{Gambar 1. Rataan Rendemen Gelatin Kulit} Ikan Tuna.

Berdasarkan gambar 1 di atas dapat dilihat bahwa nilai rendemen yang paling tinggi adalah pada perendaman larutan asam asetat $\left(\mathrm{CH}_{3} \mathrm{COOH}\right)$ 9\% dengan nilai $13,93 \%$, yang kedua pada konsentrasi $6 \%$ dengan nilai $12,52 \%$, yang ketiga $3 \%$ Rendahnya nilai rendemen yang diperoleh pada konsentrasi $0 \%$ (tanpa pemberian asam asetat) disebabkan karena tidak adanya kandungan larutan asam asetat, sedangkan pada konsentrasi 9\% diperoleh nilai rendemen yang paling tinggi karena pemberian asam asetat lebih banyak, pada $0 \%$ hampir tidak terjadi reaksi hidrolisis sehingga nilai rendemen yang diperoleh sedikit. Asam asetat pada gelatin kulit ikan tuna 
berfungsi untuk menghidrolisis kolagen sehingga pada saat ekstraksi, struktur gelatin pada kulit lebih mudah terurai. Semakin tinggi konsentrasi asam asetat yang diberikan semakin besar bobot gelatin kering yang dihasilkan. Menurut Kołodziejska $d k k$., 2007 peningkatan nilai rendemen terjadi dengan pertambahan larutan asam, nilai rendemen yang semakin tinggi menunjukkan bahwa proses produksi gelatin yang dilakukan menjadi semakin efisien. Penambahan konsentrasi larutan Asam Asetat pada teknik curing (perendaman) membuat nilai rendemen meningkat. Terjadinya peningkatan itu berkaitan dengan banyaknya jumlah kolagen yang terlepas pada saat perendaman dan mengalami perubahan menjadi gelatin.

Pemberian larutan konsentrasi pada larutan kolagen menjadi gelatin memiliki pengaruh yang sangat besar. Meningkatnya nilai rendemen berkaitan dengan banyaknya jumlah kolagen yang terkonversi dan mengalami perubahan menjadi gelatin karena pemberian larutan asam pada teknik curing. Terjadinya peningkatan konsentrasi ion $\mathrm{H}^{+}$pada teknik curing disebabkan karena adanya peningkatan konsentrasi larutan asam, yang pada akhirnya dapat mempercepat proses hidrolisis (Anonim, 2006a).

Rendahnya perendaman dengan larutan asam mempengaruhi nilai rendemen yang dihasilkan oleh gelatin kulit ikan tuna. Banyak lapisan dermis yang terlepas sehingga tidak dapat diekstraksi dan akan mudah terlepas satu dengan lainnya. Hintelwalder (1977) juga menguatkan pernyataan bahwa jika lama perendaman atau waktu perendaman tidak dilakukan dengan baik dan tepat, maka akan terjadi kelarutan kolagen yang menghasilkan nilai rendemen menjadi rendah. faktor lain juga menyebutkan rendahnya nilai rendemen disebabkan oleh proses pemekatan menggunakan evaporator vakum.

\section{Kadar Air}

Berdasarkan gambar 2 terlihat bahwa kandungan kadar air yang paling tinggi adalah pada perendaman larutan asam 6\% dengan kandungan $10,75 \%$, yang kedua nilai kadar air pada konsentrasi $9 \%$ dengan nilai $10,25 \%$, yang ketiga nilai kadar air pada konsentrasi $0 \%$ dengan nilai $9,3 \%$ dan yang paling rendah adalah 3\% dengan nilai 9,1\%.

Kadar air merupakan banyaknya air yang terkandung dalam bahan yang dinyatakan dalam persen. Kadar air juga salah satu karakteristik yang sangat penting pada bahan pangan, karena air dapat mempengaruhi penampakan, tekstur, dan citarasa pada bahan pangan. Kadar air dalam bahan pangan ikut menentukan kesegaran dan daya awet bahan pangan tersebut, kadar air yang tinggi mengakibatkan mudahnya bakteri, kapang, dan khamir untuk berkembang biak, sehingga akan terjadi perubahan pada bahan pangan (Winarno, 1997). Syarief dan Halid (1993) menyatakan bahwa peranan air dalam bahan pangan merupakan salah satu faktor yang mempengaruhi aktivitas metabolisme yaitu terjadinya ketengikan dan reaksi-reaksi nonenzimatis, sehingga menimbulkan perubahan sifat-sifat organoleptik dan nilai gizinya.

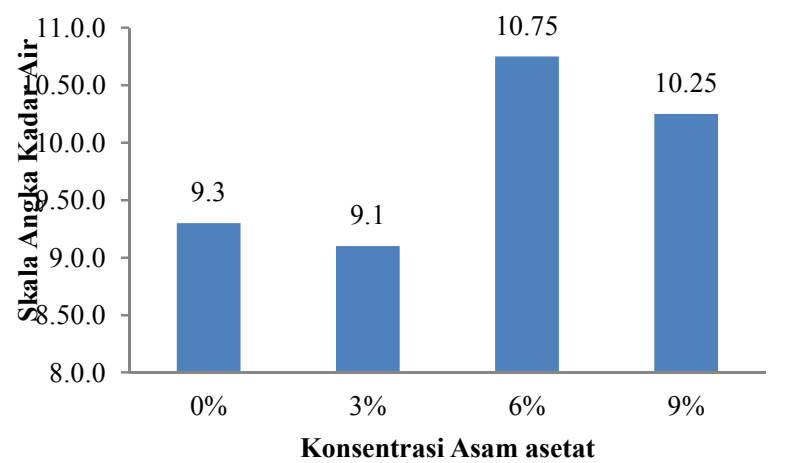

Gambar 2. Rataan Rendemen Gelatin Kulit Ikan Tuna.

Larutan asam yang diberikan pada teknik curing dapat memecah struktur asam amino yang menyusun protein pada kulit. Hal ini mengakibatkan struktur asam amino berubah menjadi sangat lemah, sehingga terjadi suatu proses yang disebut denaturasi (Muyonga et al., 2003). Proses denaturasi disebabkan karena adanya perubahan molekul dan jumlah air yang terikat menjadi lebih lemah dan menurun, menyebabkan molekul air mudah lepas sehingga pada saat dilakukan proses pengeringan nilai kadar air gelatin menjadi lebih rendah (Soeparno, 2005).

\section{TPC}

Berdasarkan hasil penelitian, data pengamatan jumlah mikroba dengan menggunakan metode TPC dengan suhu inkubasi $37^{\circ} \mathrm{C}$ dan masa simpan 24 jam dapat dilihat pada tabel 1 berikut ini.

Berdasarkan hasil penelitian total bakteri (TPC) gelatin kulit ikan tuna dilihat dari tabel 1 adalah pada konsentrasi $0 \%$ hanya 
terdapat pada pengambilan sampel ke-empat dengan nilai $7,8 \times 10^{2} \mathrm{CFU} / \mathrm{gr}$. Pada konsentrasi $3 \%$ analisa total bakteri terdapat pada pengambilan sampel ketiga dengan nilai $3,4 \times 10^{2} \mathrm{CFU} / \mathrm{gr}$ dan pengambilan sampel keempat dengan nilai $5,4 \times 10^{4} \mathrm{CFU} / \mathrm{gr}$. Untuk konsentrasi $6 \%$ analisa total bakteri terdapat pada pengambilan sampel ketiga dengan nilai $3,7 \times 10^{4} \mathrm{CFU} / \mathrm{gr}$ dan pengambilan sampel keempat dengan nilai $4,3 \times 10^{3} \mathrm{CFU} / \mathrm{gr}$. Sedangkan pada konsentrasi $9 \%$ analisa total bakteri terdapat pada pengambilan sampel ketiga dengan nilai $6,2 \times 10^{2} \mathrm{CFU} / \mathrm{gr}$ dan pengambilan sampel ke-empat dengan nilai $3,5 \times 10^{4} \mathrm{CFU} / \mathrm{gr}$.

\section{Tabel 1. Hasil Total Bakteri (TPC) Gelatin Kulit} Ikan Tuna

\begin{tabular}{ccccc}
\hline Pengambilan & \multicolumn{4}{c}{ Nilai Total Bakteri CFU/gr } \\
\cline { 2 - 5 } Sampel & $0 \%$ & $3 \%$ & $6 \%$ & $9 \%$ \\
\hline 1 & $<3$ & $\mathrm{Nd}$ & $\mathrm{Nd}$ & $<3$ \\
2 & $<3$ & $\mathrm{Nd}$ & $<3$ & $\mathrm{nd}$ \\
3 & $\mathrm{Nd}$ & $3,4 \times 10^{2}$ & $3,7 \times 10^{4}$ & $6,2 \times 10^{2}$ \\
4 & $7,8 \times 10^{2}$ & $5,4 \times 10^{4}$ & $4,3 \times 10^{3}$ & $3,5 \times 10^{4}$ \\
\hline
\end{tabular}

Sesuai dengan hasil yang diperoleh, nilai total bakteri pada gelatin ini memenuhi standar minimal yang dipersyaratkan, yaitu untuk produk gelatin minimal $1000\left(1 \times 10^{3}\right)$ atau 0,1 $\times 10^{4} \mathrm{CFU} / \mathrm{gr}$ (Anonim, 1995a; Anonim, 2004a; Anonim, 2005a) dan $5000\left(5 \times 10^{3}\right)$ atau $0,5 \times 10^{4} \mathrm{CFU} / \mathrm{gr}$ (USP. Pharmagels dalam Ockerman dan Hansen, 2000).

\section{DAFTAR PUSTAKA}

Anonim. 2006a. Gelatin.orgMarket data 2005. Gelatine Manufactures of Europe. http://www.gelatine.org. 2005a .Standar Nasional Indonesia (SNI) No. 06-3735-1995. Dewan Standarisasi Nasional.

2004a. Gelatine Food Science. www.gelatin co.za/gltnl.

2006. Gelatin Halal. www.gelatin-gmia.com/ html/gelatin_health.html. (Diakses Kamis 26 Februari 2015) 1995a. Farmakope Indonesia (FI). Edisi IV. Department Kesehatan RI, Jakarta.

1978. Mutu dan Cara Uji Gelatin. Jakarta: departemen perindustrian.

Abobinous 2013. Manfaat dan Kandungan Ikan Tuna. http:// manfaat dan kandungan. blogspot.com/2013/05/manfaat-dan-kandungan-ikantuna.html. (Diakses Jumat 12 maret 2015).

AOAC, 1984. Official Methods Of analysis of the association of analytical chemist. Inc. Washington, DC.

AOAC, 1995. Official methods of Analysis of The Association of Analytical Chemist. Inc.Washington, DC.

Badan Standarisasi nasional. 2006aDalam Tesis Umar. 2011. Cara Uji Kimia-Bagian 2: Penentuan Kadar Air Pada Produk Perikanan. SNI 01-2354.2-2006

De Man, J.M. 1997. Kimia Makanan. Penerjemah Padmawinata, K. ITB Press, Bandung.

Hinterwaldner R 1977. The Science and Technology of Gelatin. Technology of Gelatin Manufacture. Dalam Ward AG, Courts A (ed),. New York: Academy press.

Mukhtar, 2011. Manfaat Ikan Tuna. http://mukhtarapi.blogspot.com/2011/06/ada-apa-denganikan_02.html. (Diakses Kamis 26 februari 2015)

Muyonga, J.H., C.G.B. Cole and K.G. Doudu. 2004. Extraction and phsyco-chemical characterization of Nile perch (Lates niloticus) ckin and bone gelatin. Food Hydrocoloids, (18), 581-592

Soeparno. 2005. Ilmu dan Teknologi Daging. Gadjah mada University Press, Yogyakarta/

Tourtellote P, 1980. Gelatin. Di dalam encyclopedia of science and technology. New york: McGraw hill book company

Winarno, F.G . 1997. Kimia Pangan dan Gizi. Jakarta: Gramedia Pustaka Utama.

Wiratmaja, H. 2006. Perbaikan Nilai Tambah Limbah Tulang Ikan Tuna (Thunnus sp) Menjadi Gelatin Serta Analisis Sifat Fisika-Kimia [Skripsi]. Institut Pertnian Bogor. Bogor.

Yi JB, Kim YT, Bae HJ, Whiteside WS, and Park HJ. 2006. Influence of transglutaminase-induced crosslinking on properties of fish gelatin films. Journal of Food ScienceVol 71,9. 